\title{
IMPROVING PHOSPHORUS AVAILABILITY FROM PATOS PHOSPHATE ROCK FOR EUCALYPTUS: A STUDY WITH ${ }^{32}$ P RADIOTRACER
}

Felipe Carlos Alvarez Villanueva ${ }^{1,2}$; Takashi Muraoka ${ }^{1}$; Anderson Ricardo Trevizam¹; Vinicius Ide Franzini ${ }^{3}$; Alexandre Prado Rocha ${ }^{4}$

${ }^{1}$ USP/CENA - Lab. de Fertilidade do Solo, C.P. 96 - 13400-970 - Piracicaba, SP - Brasil.

${ }^{2}$ INIFAT - Lab. de Trazadores Isotópicos, Calle 1 - CP 17250 - Santiago de las Vegas, C. de la Habana - Cuba. ${ }^{3}$ USP/ESALQ - Programa de Pós-Graduação em Solos e Nutrição de Plantas, C.P. 9 - 13418-900 - Piracicaba, SP - Brasil.

${ }^{4}$ Escola de Engenharia de Piracicaba, Av. Monsenhor Martinho Salgot, 560 - 13414-040 - Piracicaba, SP Brasil.

*Corresponding author <falvarez@cena.usp.br>

ABSTRACT: Eucalyptus plantation in Brazil is generally set on low fertility soils, therefore phosphorus (P) fertilization is mandatory and increases the cost of plantation operation. Using species that more efficiently uptake phosphorus from less soluble sources is an interesting option. However, little is known about eucalyptus regarding its ability of using less soluble forms of phosphorus. The use of $\mathrm{P}$ by eucalyptus (E. urophylla, E. grandis, and E. urophylla $\times$ E. grandis) was studied in greenhouse using a loamy-textured, hipodystrophic Typic Haplustox from the Cerrado region, and ${ }^{32} \mathrm{P}$ isotopic method. The P sources tested were triple superphosphate (TSP), phosphate rock (PR) and the triple superphosphate mixed with PR $(\mathrm{TSP}+\mathrm{PR})$. The effectiveness of $\mathrm{P}$ sources in terms of increasing dry matter yield was TSP $=(\mathrm{TSP}+\mathrm{PR})$ $>$ PR, and the P uptake followed the order (TSP + PR) > TSP > PR for both species plus the hybrid. The increase in P uptake from PR due to TSP influence was $217.3 \%$ for E. urophylla, $235.7 \%$ for E. grandis, and $28.7 \%$ for $E$. urophylla $\times E$. grandis, indicating an enhancement effect of TSP on the effectiveness of PR. The hybrid E. urophylla $\times E$. grandis was the most efficient genotype on P soil use and E. grandis most exigent in $\mathrm{P}$ fertilizer.

Key words: L value, P sources, radioisotope

\section{MELHORANDO A DISPONIBILIDADE DE FÓSFORO DA ROCHA FOSFÓRICA DE PATOS PARA EUCALIPTO: UM ESTUDO COM RADIOTRAÇADOR ${ }^{32} \mathrm{P}$}

\begin{abstract}
RESUMO: Como geralmente os solos usados para plantações de eucalipto no Brasil são de baixa fertilidade, a adubação fosfórica é indispensável, incrementando o custo da plantação. Espécies mais eficientes no uso de fósforo $(\mathrm{P})$ de fontes pouco solúveis poderiam ser uma opção interessante. Porém, pouco se conhece ainda sobre o comportamento de eucalipto em relação à capacidade de usar fósforo de fontes com diferente solubilidade em água. O uso de P por eucalipto (E. urophylla, E. grandis, and E. urophylla $\times$ E. grandis), foi estudado em experimento de casa de vegetação usando solo da Região de Cerrado, Latossolo Vermelho Amarelo hypodistrófico, e o método isotópico $\operatorname{com}^{32} \mathrm{P}$. As fontes de $\mathrm{P}$ usadas foram superfosfato triplo (SFT), rocha fosfórica (RF) e a mistura de superfosfato triplo com rocha fosfórica (SFT+RF). A eficácia das fontes de $\mathrm{P}$ em termos do aumento do rendimento de matéria seca seguiu a ordem $\mathrm{SFT}=(\mathrm{SFT}+\mathrm{RF})$ $>$ RF e de $\mathrm{P}$ absorvido a ordem $(\mathrm{SFT}+\mathrm{RF})>\mathrm{SFT}>\mathrm{RF}$ por ambas as espécies e o híbrido de eucalipto. O incremento na absorção de P de RF, influenciada pela mistura com SFT foi de 217,3\% em E. urophylla, $235,7 \%$ em $E$. grandis e $28,7 \%$ em E. urophylla $\times E$. grandis, indicando o efeito benéfico do SFT sobre a efetividade da RF. O híbrido E. urophylla $\times E$. grandis foi o genótipo mais eficiente no uso de P do solo e E. grandis o mais exigente em $\mathrm{P}$ do fertilizante.

Palavras-chave: valor $L$, fontes de fósforo, radioisótopo
\end{abstract}

\section{INTRODUCTION}

Eucalyptus plantations for cellulose, wood, charcoal, sawbuck, and essential oils production in
Brazil exceeds 2.5 million hectares (ABRACAVE, 2001). Most of this area is in the savanna region, where soils are generally infertile, have low base saturation, high aluminum saturation, and are highly acidic. The 
eucalyptus production is impaired under these conditions by soil $\mathrm{P}$ deficiency, due to low availability and high P fixation capacity of these soils (Sanchez \& Salinas, 1981). Phosphorus fertilization is necessary for eucalyptus plantations in this scenario and increases the cost for installation and handling of plantations. The large, initial phosphorus demand by eucalypts justify the amounts of soluble $\mathrm{P}$ fertilizer recommended (Barros et al., 1990).

Phosphate rock (PR) application is an interesting, low-cost phosphorus source option, especially in areas close to mines (Barros \& Novais, 1996). For soils with low $\mathrm{P}$ availability or high phosphorus-fixing capacity, broadcast application of PR associated with localized addition of soluble $\mathrm{P}$ sources is recommended to improve and maintain eucalyptus productivity (Barros \& Novais, 1996). However, little is known about the eucalyptus species regarding its usage of water-insoluble P sources, directly applied or mixed with soluble sources. On the other hand, using waterinsoluble $\mathrm{P}$ sources for plants adaptated to low fertility soils and which absorb less available $\mathrm{P}$, may result in higher profits for small farmers.

The ${ }^{32} \mathrm{P}$ method has been shown to be better than conventional methods to evaluate and compare species in relation to $\mathrm{P}$ absorption from different sources (Hocking, 1980; Muraoka, 1991; Zapata \& Axmann, 1995; Chien et al., 1996; Fernandes \& Muraoka, 2002). The objective of this study was to evaluate $\mathrm{P}$ absorption and utilization by two eucalyptus species and their hybrid. Low solubility P source applied alone or mixed with triple superphosphate (TSP) were evaluated using the radiotracer ${ }^{32} \mathrm{P}$ method.

\section{MATERIAL AND METHODS}

The soil used was a loamy-textured, typic Haplustox with natural vegetation at Planaltina de Goiás, State of Goiás, Brazil, an area within the Brazilian central "Cerrado" $\left(15^{\circ} 14^{\prime} \mathrm{S}, 47^{\circ} 42^{\prime} \mathrm{W}\right.$, altitude $826 \mathrm{~m})$. The soil was collected at the $0-20 \mathrm{~cm}$ layer, air-dried, homogenized and sieved through a $4 \mathrm{~mm}$ screen for pot experiments, and $2 \mathrm{~mm}$ screen for analysis. The main soil chemical and physical properties were analyzed according to standard analytical methods recommended by Camargo et al. (1986); and Raij et al. (1987) and were: $\mathrm{pH}\left(\mathrm{CaCl}_{2} 0,01 \mathrm{~mol} \mathrm{~L}^{-1}\right)=4.12$; organic matter $=22.55 \mathrm{~g} \mathrm{dm}^{-3} ; \mathrm{P}^{2}$ resin $=5.40 \mathrm{mg} \mathrm{dm}^{-3}$; $\mathrm{K}=1.60 \mathrm{mmol}_{\mathrm{c}} \mathrm{dm}^{-3} ; \mathrm{Ca}=1.49 \mathrm{mmol}_{\mathrm{c}} \mathrm{dm}^{-3} ; \mathrm{Mg}=$ $1.51 \mathrm{mmol}_{\mathrm{c}} \mathrm{dm}^{-\mathrm{c}} ; \mathrm{H}+\mathrm{Al}=65.81 \mathrm{mmol}_{\mathrm{c}} \mathrm{dm}^{-3} ; \mathrm{CEC}=$ $70.41 \mathrm{mmol} \mathrm{dm}^{-3}$; sum of bases $=4.60 \mathrm{mmol} \mathrm{dm}^{-3} ; \mathrm{V}$ (base saturation) $=6.50 \%$; sand $=276 \mathrm{~g} \mathrm{dm}^{-3}$; silt $=$ $324 \mathrm{~g} \mathrm{dm}^{-3}$, and clay $=410 \mathrm{~g} \mathrm{dm}^{-3}$.
Two eucalyptus species (E. urophylla, E. grandis), and the hybrid (E. urophylla $\times$ E. grandis), cultivars commonly grown in Brazil, were used in the experiment. Seed was supplied by the "Departamento de Ciências Florestais" (USP/ESALQ), Piracicaba, SP.

Studied P sources were triple superphosphate (TSP) and Patos de Minas (Brazil) PR, both finely ground $(0.15 \mathrm{~mm}$ or $100 \mathrm{mesh})$, and TSP mixed with PR. For each cultivar, four treatments were established: 1) reference or standard (without P); 2) 100 $\mathrm{mg} \mathrm{dm} \mathrm{dm}^{-3} \mathrm{P}$ as TSP; 3) $400 \mathrm{mg} \mathrm{dm} \mathrm{P}^{-3} \mathrm{~Pa} \mathrm{PR}$; and 4) $50 \mathrm{mg} \mathrm{dm}^{-3} \mathrm{P}$ as TSP $+400 \mathrm{mg} \mathrm{dm} \mathrm{dm}^{-3} \mathrm{P}$ as PR. The experiment was set in a $3 \times 3$ complete factorial scheme ( 3 cultivars and $3 \mathrm{P}$ sources more one reference/standard), completely randomized block design $(\mathrm{n}=3)$. Characteristics (total P, soluble $\mathrm{P}$ in neutral ammonium citrate, citric acid and water) of $\mathrm{P}$ sources used are listed in Table 1.

Plants were grown in plastic pots lined with polyethylene bags and filled with $1 \mathrm{dm}^{-3}$ of soil. The isotopic, indirect approach was used to assess the $\mathrm{P}$ availability from the P sources (Muraoka, 1991; Zapata \& Axmann, 1995; Chien et al., 1996). An aliquot of $100 \mathrm{~mL}$ solution containing $3.7 \mathrm{MBq}{ }^{32} \mathrm{P}$ per pot was added to soil to obtain sufficient activity in the plant material, and was left drying for two days. The ${ }^{32} \mathrm{P}-\mathrm{la}-$ belled carrier solution was prepared by adding the total activity required for the experiment as ${ }^{32} \mathrm{P}$ carrierfree to $\mathrm{KH}_{2} \mathrm{PO}_{4}$ carrier solution with $50 \mathrm{mg} \mathrm{L}^{-1} \mathrm{P}$. The soil in pot was incubated by seven days, keeping the soil moisture to $70 \%$ of the field capacity after receiving the phosphate source, $55 \mathrm{mg} \mathrm{dm}^{-3}$ of $\mathrm{N}$ as urea, 52 $\mathrm{mg} \mathrm{dm}{ }^{-3}$ of $\mathrm{K}_{\text {as }} \mathrm{K}_{2} \mathrm{SO}_{4}$, and calcium and magnesium mixtures (carbonates) in the $4: 1$ proportion. Calcium and magnesium carbonates were supplied as calcium and magnesium sources rather than for $\mathrm{pH}$ amendment, hence eucalypts are seemingly tolerant to aluminum and low soil pH (Barros \& Novais, 1996).

Sixty-five day old seedlings, grown in washedsand, of each eucalyptus species plus the hybrid were transplanted to each pot. Five days later, pots were thinned to three seedlings and soil moisture content

Table 1 - Characteristics of $\mathrm{P}$ sources used.

\begin{tabular}{lcc}
\hline Indice & TSP & PR \\
\hline Total P & 19.65 & 10.04 \\
$\mathrm{P}_{\mathrm{NAC}}$ & 19.21 & 0.66 \\
$\mathrm{P}_{\mathrm{CA}}$ & 17.47 & 1.75 \\
$\mathrm{P}_{\mathrm{H}_{2} \mathrm{O}}$ & 87.00 & - \\
\hline $\mathrm{P}_{\mathrm{NAC}}=\mathrm{P}$ soluble in neutral ammonium citrate; $\mathrm{P}_{\mathrm{CA}}=$ P soluble in \\
citric acid $2 \%$ and $\mathrm{P}_{\mathrm{H}_{2} \mathrm{O}}=\mathrm{P}$ soluble in water.
\end{tabular}


was maintained to $70 \%$ of the field capacity. A micronutrient solution (Sarruge, 1975) containing Mn, Fe, $\mathrm{Cu}, \mathrm{Zn}, \mathrm{B}$, and $\mathrm{Mo}$, was added to each pot $(15 \mathrm{~mL})$ when the plants were two, four, and six weeks old.

Harvesting was done by cutting the aboveground part of the plants, 55 days after planting. Plant samples were washed with deionized water, oven-dried at $70^{\circ} \mathrm{C}$ and weighed. The dried plant material was ground in a Wiley mill, digested in a nitro-perchloric acids, and the $\mathrm{P}$ concentration determined using the ammonium molybdate method (Bataglia et al., 1983); the ${ }^{32} \mathrm{P}$ activity was determined with the Cerenkov effect in a Liquid Scintillation counter, whit quenching correction by channel relation (Nascimento Filho \& Lobão, 1977).

Based on the isotopic dilution method, the proportion of $\mathrm{P}$ in plants from soil, TSP, and PR were calculated according to Muraoka (1991), Zapata \& Axmann (1995), and Chien et al. (1996). The fractions of TSP and PR from (TSP + PR) treatment were calculated as follows:

$$
\begin{aligned}
& F P_{\text {soil }(T S P+P R)}=\left[\frac{S A p_{(T S P+P R)}}{S A p_{(\text {standard })}}\right] \\
& F P_{(T S P+P R)}=1-F P_{\text {soil }(T S P+P R)} \\
& P_{\text {soil }(T S P+P R)}=P_{p(T S P+P R)} x F P_{\text {soil }(T S P+P R)} \\
& P_{(T S P+P R)}=P_{p(T S P+P R)} x F P_{(T S P+P R)}
\end{aligned}
$$

where: $F P_{\text {soil }(T S P+P R)}=$ fraction of $\mathrm{P}$ uptake from soil in $(\mathrm{TSP}+\mathrm{PR})$ treatment; $S A p_{(T S P+P R)}=$ specific activity of $\mathrm{P}$ in plants $\left(\mathrm{cpm} \mathrm{mg}{ }^{-1} \mathrm{P}\right)$ from (TSP $\left.+\mathrm{PR}\right)$ treatment; $S A p_{(\text {standard })}=$ specific activity of $\mathrm{P}$ in plants $(\mathrm{cpm} \mathrm{mg}$ P) from reference/standard treatment; $F P_{(T S P+P R)}=$ fraction of $\mathrm{P}$ uptake from TSP and PR by plants in (TSP $+\mathrm{PR})$ treatment; $P_{\text {soil }(T S P+P R)}=\mathrm{P}$ uptake from soil by plants in $(\mathrm{TSP}+\mathrm{PR})$ treatment; $P_{(T S P+P R)}=\mathrm{P}$ uptake from TSP and PR by plants in (TSP + PR) treatment; $P_{p(T S P+P R)}=\mathrm{P}$ total in above ground-part of plants of (TSP + PR) treatment;

$$
\begin{aligned}
& F P_{(\text {soil }+P R)}=\left[\frac{S A p_{(T S P+P R)}}{S A p_{(P R)}}\right] \\
& F P_{T S P(T S P+P R)}=1-F P_{(\text {soil }+P R)} \\
& P_{(\text {soil }+P R)}=P_{p(T S P+P R)} x F P_{(\text {soil }+P R)} \\
& P_{T S P(T S P+P R)}=P_{p(T S P+P R)} x F P_{T S P(T S P+P R)}
\end{aligned}
$$

where: $F P_{(s o i l+P R)}=$ fraction of $\mathrm{P}$ uptake from soil and $\mathrm{PR}$ by plants in (TSP+PR) treatment; $S A p_{(\text {soil }+P R)}=$ specific activity of $\mathrm{P}$ in plants $\left(\mathrm{cpm} \mathrm{m} \mathrm{m}^{-1} \mathrm{P}\right)$ from (PR) treatment; $F P_{T S P(T S P+P R)}=$ fraction of $\mathrm{P}$ uptake from TSP by plants in (TSP + PR) treatment; $P_{(s o i l+P R)}=\mathrm{P}$ uptake from soil and PR by plants in (TSP + PR) treatment; $P_{T S P(T S P+P R)}=\mathrm{P}$ uptake from TSP by plants in (TSP + PR) treatment; and

$$
P_{P R(T S P+P R)}=P_{(\text {soil }+P R)}-P_{\text {soil }(T S P+P R)}([7]-[3])
$$

where: $P_{P R(T S P+P R)}=\mathrm{P}$ uptake from PR by plants in (TSP + PR) treatment

\section{RAE (\%) (Relative agronomic efficiency)}

The RAE was calculated as:

$$
R A E(\%)=\frac{Y_{1}-Y_{o}}{Y_{2}-Y_{o}} \times 100
$$

where: $Y_{1}$ is the dry matter yield or $\mathrm{P}$ uptake in PR or (TSP + PR) treatments; $Y_{2}$ is the dry matter yield or P uptake in TSP treatment; $Y_{0}$ is the dry matter yield or $\mathrm{P}$ uptake in standard treatment (without added P).

All data were submitted to analysis of variance (F test) followed by Tukey's test $(\alpha=0.05)$ for mean comparison using the SAS system software (SAS, 1996).

\section{RESULTS AND DISCUSSION}

Dry matter yield and P uptake were significantly increased by P application (Tables 2 and 3 ). The low dry matter yield and P uptake in both species and the hybrid in the standard treatment without $\mathrm{P}$ addition indicate very low $\mathrm{P}$ availability in the soil, and eucalypt sensitivity to deficiency of $\mathrm{P}$ in the soil.

The effectiveness of $\mathrm{P}$ sources in increasing dry matter yield and $\mathrm{P}$ uptake followed the order (PR + TSP $)=$ TSP $>$ PR for both species and the hybrid, and the increasing P uptake was (PR + TSP) $>$ TSP $>$ PR. The hybrid E. urophylla $x$ E. grandis had the highest dry matter yield and $\mathrm{P}$ uptake from all $\mathrm{P}$ sources.

The lower dry matter yield and P uptake of PR resulted from its lower solubility (Table 1). The "Patos de Minas" PR utilized in this work has low reactivity and solubility in water, with $\mathrm{P}$ in the form of fluor-carbonate-apatite or a mixture of fluorapatite and carbonate-apatite (Marciano et al., 1990). The solubility of this PR is facilitated by isomorphic substitution of phosphate by carbonate or fluorine in its structure (Khasawneh \& Doll, 1978). On the other hand, low efficiency of PR in acid and loamy soils with low avail- 
Table 2 - Above ground dry matter weight of two eucalyptus species and the hybrid as affected by different P sources.

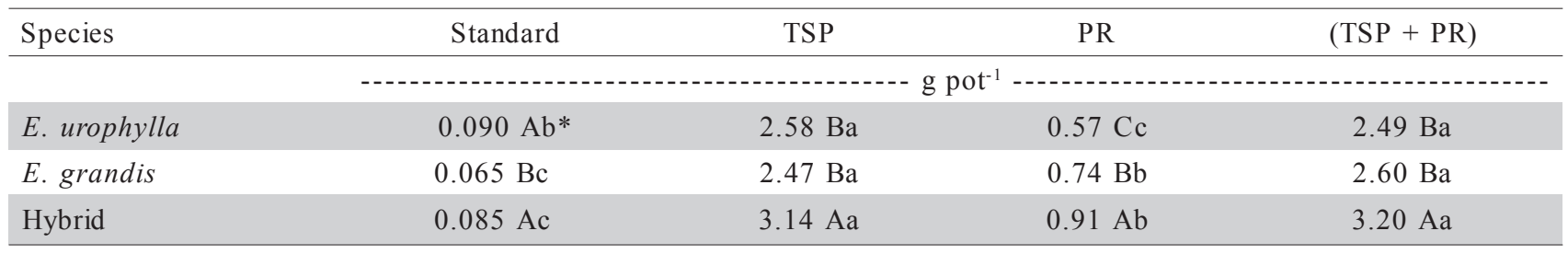

*Values followed by the same letters (capital letter in columns between species, and lower case letter in row between $\mathrm{P}$ source) do not different $(P<0.05)$ by Tukey multiple range test.

Table 3 - Phosphorus taken up by two eucalyptus species and the hybrid as affected by different P sources.

\begin{tabular}{lcccc}
\hline Species & Standard & TSP & PR & (TSP + PR) \\
\hline & $0.042 \mathrm{Ad}^{*}$ & $2.91 \mathrm{Bb}$ & $1.06 \mathrm{Bc}$ & $4.29 \mathrm{Ba}$ \\
E. urophylla & $0.025 \mathrm{Bd}$ & $2.75 \mathrm{Bb}$ & $1.43 \mathrm{Ac}$ & $4.58 \mathrm{Ba}$ \\
E. grandis & $0.050 \mathrm{Ad}$ & $4.01 \mathrm{Ab}$ & $1.60 \mathrm{Ac}$ & $5.50 \mathrm{Aa}$ \\
\hline Hybrid & & &
\end{tabular}

*Values followed by the same letters (capital letter in columns between species, and lower case letter in row between $\mathrm{P}$ source) do not differ $(P<0.05)$ by Tukey multiple range test.

able $\mathrm{P}$ is due to reactions of adsorption and fixation of P, limiting the use by plants (Novais \& Smyth, 1999).

The RAE in dry matter yield (Table 4) increased from $19 \%$ with PR to $96 \%$ with (TSP + PR) in E. urophylla, and from $27 \%$ with PR to $103 \%$ as average to E. grandis and E. urophylla $x$ E. grandis with (TSP + PR).

The P uptake increased from $35 \%, 50 \%$ and $39 \%$ with PR to $148 \%, 167 \%$ and $137 \%$ with (TSP + PR) in E. urophylla, E. grandis and E. urophylla $\times$ E. grandis, respectively. The RAE of PR and (TSP + PR) was higher for $E$. grandis than E. urophylla and $E$. urophylla $x E$. grandis. The acidification in the rhizosphere environment by the exudation of organic acids, together with higher root development, could be mechanisms for the genotypic difference in P uptake from different $\mathrm{P}$ sources (Bekele et al., 1983). A greater response of $E$. grandis seedlings to high $\mathrm{P}$ levels and use of $\mathrm{P}$ fertilizer among five other eucalypt species was reported by Furtini Neto et al. (1996).

The P uptake from TSP and PR in treatments they were applied alone (Table 5) was calculated from the FPdfTSP (fraction of $\mathrm{P}$ in plant derived from TSP), and $F P d f P R$ (fraction of $\mathrm{P}$ in plant derived from $\mathrm{PR}$ ) according to Muraoka (1991), Zapata \& Axmann (1995), and Chien et al. (1996). The P uptake from each P source $\left(P_{T S P(T S P+P R)}\right.$ and $\left.P_{P R(T S P+P R)}\right)$ in the (TSP + PR) treatment (Table 5), was calculated from de fractions $F P_{T S P(T S P+P R)}$, equations [6] and [8], and $F P_{P R(T S P}$ $+P R)$, equations [3], [7] and [9]. The P uptake from PR in the presence of TSP was higher than that from PR alone. Thus, $\mathrm{P}$ uptake from PR was enhanced when applied with TSP. The increase in P uptake from PR
Table 4 - Relative agronomy effectiveness (RAE) for dry matter yield and $\mathrm{P}$ uptake obtained with various P sources.

\begin{tabular}{lccccc}
\hline \multirow{2}{*}{ Species } & \multicolumn{2}{c}{ Dry matter yield } & & \multicolumn{2}{c}{ P uptake } \\
\cline { 2 - 3 } \cline { 5 - 6 } \cline { 5 - 6 } & PR & $(\mathrm{PR}+\mathrm{TSP})$ & & PR & $(\mathrm{TSP}+\mathrm{PR})$ \\
\hline E. urophylla & 19 & 96 & & 35 & 148 \\
E. grandis & 27 & 105 & & 50 & 167 \\
Hybrid & 27 & 102 & & 39 & 137 \\
\hline
\end{tabular}

$\mathrm{PR}=$ phosphate rock; TSP $=$ triple superphosphate

Table 5 - P uptake by two species of eucalyptus and the hybrid from TSP and PR applied alone or together with TSP.

\begin{tabular}{|c|c|c|c|c|}
\hline Species & $\mathrm{P}_{\mathrm{TSP}}$ & $P_{P R}$ & $\mathrm{P}_{\mathrm{PR}(\mathrm{TSP}+\mathrm{PR})}$ & $\mathrm{P}_{\mathrm{TSP}(\mathrm{TSP}+\mathrm{PR})}$ \\
\hline \multicolumn{5}{|c|}{ ng P pot ${ }^{-1} \ldots$} \\
\hline E. urophylla & $2.13 \mathrm{Ba}^{*}$ & $0.69 \mathrm{Bc}$ & $2.19 \mathrm{Ba}$ & $1.21 \mathrm{Bb}$ \\
\hline E. grandis & $2.54 \mathrm{Ab}$ & $1.23 \mathrm{Ac}$ & $4.13 \mathrm{Aa}$ & $0.11 \mathrm{Cd}$ \\
\hline Hybrid & $1.40 \mathrm{Cb}$ & $0.80 \mathrm{Bd}$ & $1.03 \mathrm{Cc}$ & $2.18 \mathrm{Aa}$ \\
\hline
\end{tabular}

*Values followed by the same letters (capital letter in columns between species, and lower case letter in row between $\mathrm{P}$ source) do not differ $(P<0.05)$ by Tukey multiple range test.

due to TSP was $217.3 \%$ for E. urophylla, $235.7 \%$ for E. grandis and $28.7 \%$ for the hybrid.

Three major causes may explain this behavior of the eucalyptus seedlings and enhance of the P uptake from PR: a) the partial solubilization of the PR by the acidity of the TSP; b) the "priming effect" of the TSP increased the development of seedling root and enabled the plant to use P from PR more effectively than it could with $\mathrm{PR}$ alone; c) higher rate of $\mathrm{P}$ in the (TSP + PR) treatment in relation to others treat- 
ments. E. grandis was the eucalyptus specie with higher use of P from PR and TSP as is shown by the $\mathrm{RAE} \%$. This specie of eucalyptus was the most responsive to high rate of $\mathrm{P}$ applied among five other species (Furtini Neto et al., 1996).

\section{AKNOWLEDGMENTS}

To CNPq for scholarships and the International Atomic Energy Agency, Vienna, Austria for the financial support under IAEA Research Contract BRA10954/RB.

\section{REFERENCES}

ASSOCIAÇÃO BRASILEIRA DE FLORESTAS RENOVÁVEIS. Anuário estatístico ABRACAVE. Belo Horizonte: ABRACAVE, 2001. 235p.

BARROS, N.F.; NOVAIS R.F. Eucalypt nutrition and fertilizer regimes in Brazil. In: ATTIWIL, P.M.; ADAMS, M.A. (Ed.) Nutrition of Eucalyptus. Melbourne: CSIRO, 1996. p.335-355.

BARROS, N.F.; NOVAIS. R.F.; NEVES, J.C.L. Fertilização e correção do solo para o plantio de eucalipto. In: BARROS, N.F.; NOVAIS, R.F. (Ed.) Relação solo-eucalipto. Viçosa: Folha de Viçosa, 1990. p.127-186.

BATAGLIA, O.C.; FURLANI, A.M.C.; TEIXEIRA, J.P.F.; FURLANI, P.R.; GALLO, J.R. Método de análise química de plantas. Campinas: Instituto Agronómico, 1983. 48p. (Boletim Técnico, 78).

BEKELE, T.; CINO, B.J.; EHLERT, P.A.; VAN DER MASS, A.A.; VAN DIEST, A. An evaluation of plant-borne factors promoting the solubilization of alkaline rock phosphate. Plant and Soil, v.75, p.361378, 1983.

CAMARGO, L.C.; MONIZ, A.C.; JORGE, J.A.; VALADARES, J.M.A.S. Métodos de análise química, mineralógica e física de solos do Instituto Agronômico de Campinas. Campinas: IAC, 1986. 94p. (Boletim Técnico, 106).

CHIEN, S.H.; MENON, R.G.; BILlingHAM, K.S. Phosphorus availability from phosphate rock as enhanced by water-soluble phosphorus. Soil Science Society of America Journal, v.60, p.1173$1177,1996$.
FERNANDES, C.; MURAOKA, T. Absorção de fósforo por híbridos de milho cultivados em solo de cerrado. Scientia Agricola, v.59, p.781-787, 2002.

FURTINI NETO, A.E.; BARROS, N.F.; GODOY, M.F.; NOVAIS, R.F. Eficiência nutricional de mudas de Eucalyptus em relação a fósforo. Revista Árvore, v.20, p.17-28, 1996.

HOCKING, P.J. Redistribution of nutrient elements from cotyledons of two species of annual legumes during germination and seedling growth. Annals of Botany, v.45, p.383-396, 1980.

KHASAWNEH, F.E.; DOLL, E.C. The use of phosphate rock for direct application to soils. Advances in Agronomy, v.30, p.159-206, 1978.

MARCIANO, A.; RODRIGUEZ, A.J.; ARAÚJO, A.C. Caracterização tecnológica do fosfato de Patos de Minas. In: SIMPÓSIO EPUSP DE CARACTERIZAÇÃO TECNOLÓGICA NA ENGENHARIA E INDÚSTRIA MINERAL, 1., São Paulo, 1990. Anais. São Paulo: EPUSP, 1990. p.281-991.

MURAOKA, T. Uso de técnicas isotópicas em fertilidade do solo. In: OLIVEIRA, A.J.; GARRIDO, W.E.; ARAUJO, J.D. de; LOURENÇO, S. (Coord.) Metodologia de pesquisa em fertilidade do solo. Brasília: EMBRAPA, SEA, 1991. p.255-273.

NASCIMENTO FILHO, V.F.; LOBÃO, A.E. Detecção de ${ }^{32} \mathbf{P}$ em amostras de origem animal e vegetal por efeito Cerenkov, cintilação líquida e detector GM. Piracicaba: CENA/USP, 1977. (Boletim Científico, 48).

NOVAIS, R.F.; SMYTH, T.J. Fósforo em solo e planta em condições tropicais. 1.ed. Viçosa: UFV, DPS, 1999. 399p.

RAIJ, B. van; QUAGGIO, J.A.; CANTARELLA, H.; FERREIRA, M.E.; LOPES, A.S.; BATAGLIA, O.C. Análise química do solo para fins de fertilidade. Campinas: Fundação Cargill, 1987. 170p.

SANCHEZ, P.A.; SALINAS, J.G. Low input technology for managing Oxisols and Ultisols in Tropical America. Advances in Agronomy, v.34, p.280-406, 1981.

SAS INSTITUTE. SAS/STAT user's guide. Version 6.11. 4.ed. Cary: SAS Inc., 1996. 842p.

SARRUGE, J.R.. Soluções nutritivas. Summa Phytopatologica, v.1, p.231-233, 1975.

ZAPATA, F.; AXMANN, H. ${ }^{32} \mathrm{P}$ isotopic techniques for evaluation the agronomic effectiveness of rock phosphate materials. Fertilizer Research, v.41, p.189-195, 1995.

Received March 08, 2005

Accepted December 28, 2005 